\title{
Measuring Consumers' Environmental Responsibility: A Synthesis of Constructs and Measurement Scale Items
}

\author{
K.M.R. TAUFIQUE ${ }^{* 1}$, C.B. SIWAR ${ }^{1}$, B.A. TALIB $^{2}$ and NORSHAMLIZA CHAMHURI ${ }^{2}$ \\ ${ }^{1}$ Institute for Environment and Development, Universiti Kebangsaan Malaysia, \\ 43600, Bangi, Selangor, Malaysia. \\ ${ }^{2}$ Faculty of Economics and Management, UniversitiKebangsaan Malaysia \\ 43600, Bangi, Selangor, Malaysia.
}

http://dx.doi.org/10.12944/CWE.9.1.04

(Received: January 27, 2014; Accepted: March 24, 2014)

\begin{abstract}
It is universal that central to all production is consumption. Without proper management, production along with consumption is likely to be the main sources of environmental problems. This very reality calls for consumers to be environmentally responsible in their consumption behavior. The objective of this paper is to prepare a synthesis of all the possible factors and measurement scale items to be used for assessing consumers' environmental responsibility. For making such synthesis, all major works done on the field have been thoroughly reviewed. The paper comes up with a total of six parameters that include knowledge \& awareness, attitude, green consumer value, emotional affinity toward nature, willingness to act and environment related past behavior. These tentative, yet inclusive set of parameters are thought to be useful for guiding the designing of large scale future empirical researches for developing a dependable inclusive set of parameters to test consumer' environmental responsibility. A conceptual model and possible measurement items are proposed for further empirical research.
\end{abstract}

Key words: Consumer, Environmental responsibility, Parameters, Measurement, Review, Conceptual model.

\section{INTRODUCTION}

Consumption is considered to be central to all production. It is used as an indicator to measure the well-being of individuals and household and to improve the quality of life (Magrabi, 1991). However, without proper management, production along with consumption is the main sources of environmental problems (Haron et al., 2005). The reason for this is that the by-products of most consumption are pollution and a fall in the usefulness of energy materials for future consumption (Trott, 1997). Conclusions of many studies have argued that irresponsible consumption behavior is responsible for a significant part of environmental deterioration. Tuna and Özkoçak (2012) suggest that unconscious usage of natural resources for the requirements of humanity and inconsiderate consumption habits of the people have led to irreversible environmental destructions. They further argue that more energy-consuming human activities aiming at satisfying the so-called "well-being" and "comfort" of humanity have contributed to the gradual depletion of energy resources. Miran et al. (2008) claim that it is likely that our planet and all its inhabitants are today threatened by a potential global ecological crisis.

The overuse of nature resources for human purposes and its long term adverse impact made us recognize the human responsibility towards nature. One facet of this recognition is evidenced in the development of eco-friendly consumption patterns among consumers. One study (Grunert, 1993) reported that about 40 percent of environmental degradation has been accounted for by the consumption activities of private household level. 
It is thus well evidenced and believed that consumption and consumer behavior at household level are, by and large, responsible for environmental degradation. Accordingly, along with other governing bodies, consumers need to be involved in the journey to environmentally sustainable consumption behavior in order for an economy to grow "green". The starting point for such journey with consumers is to know their present status regarding their understanding of the issue and how environmentally responsible they are in their consumption behavior. Investigation of this kind is not a straightforward work since the issue is very much latent in nature. The prerequisite for such study calls for an all inclusive set of parameters generated from a comprehensive literature survey.

\section{MATERIALS AND METHODS}

The study is solely based on a comprehensive and systematic review of literature. Several steps have been gone through in searching and selecting the literature for being reviewed. First a very general and broad search was conducted in Google using the key phrases reflecting the topic of the study. Databases such as EBSCO, Emarald, ScienceDirect, SCOPUS etc. were accessed to search for the relevant research papers. Finally as suggested by Randolph (2009), the references of the retrieved articles were repeatedly searched until a point of saturation was reached. After that the inclusion of the articles was narrowed down to match the focus of this paper following the review guidelines of Hart (1998).

Table 1: Summary of the Constructs for Assessing Consumers' Environmental Responsibility

\begin{tabular}{|c|c|c|}
\hline Construct & Reference & Key Argument \\
\hline $\begin{array}{l}\text { Knowledge and } \\
\text { Awareness }\end{array}$ & $\begin{array}{l}\text { Stone et al. (1995); Maloney and Ward } \\
\text { (1973); Hines, Hungerford, and Tomera } \\
(1986)\end{array}$ & $\begin{array}{l}\text { Environmentally responsible } \\
\text { consumers must have knowledge } \\
\text { and awareness of the environment. }\end{array}$ \\
\hline Attitude & $\begin{array}{l}\text { Dunlap \& Van Liere(1978); Jackson (1985); } \\
\text { Kinnear, Taylor, \& Ahmed (1974); Maloney } \\
\text { \& Ward (1973); Thompson \&Gasteigner } \\
\text { (1985). }\end{array}$ & $\begin{array}{l}\text { Attitude is one of the key elements } \\
\text { of an individual's environmental } \\
\text { responsibility. }\end{array}$ \\
\hline $\begin{array}{l}\text { Green Consumer } \\
\text { Value }\end{array}$ & Haws, Winterich, and Naylor (2010) & $\begin{array}{l}\text { Environmentally sustainable } \\
\text { consumption behavior is associated } \\
\text { with the degree of consumers' } \\
\text { green values. }\end{array}$ \\
\hline $\begin{array}{l}\text { Emotional Affinity } \\
\text { toward Nature }\end{array}$ & $\begin{array}{l}\text { Kals, Schumacher,\& Montada, } \\
\text { 1999; Müller, Kals, \&Pansa, 2009; } \\
\text { Stern, } 2000\end{array}$ & $\begin{array}{l}\text { The extent to which a person has } \\
\text { an emotiona connection to his or } \\
\text { her natural environment has impact } \\
\text { on individual's commitment to be } \\
\text { responsible for the protection } \\
\text { of environment. }\end{array}$ \\
\hline Willingness to Act & $\begin{array}{l}\text { Maloney \& Ward (1973); Hines } \\
\text { et al. (1986); Berkowitz and } \\
\text { Daniels (1964) }\end{array}$ & $\begin{array}{l}\text { Verbal commitment is a measure } \\
\text { for individual's willingness to act. } \\
\text { Personality factors and social } \\
\text { responsibility are also associated } \\
\text { with one's willingness to act. }\end{array}$ \\
\hline $\begin{array}{l}\text { Action Taken/ } \\
\text { Environment } \\
\text { Related Past } \\
\text { Behavior }\end{array}$ & $\begin{array}{l}\text { Bennet (1974); Dunlap \& } \\
\text { Van Liere (1978) }\end{array}$ & $\begin{array}{l}\text { The engagement in certain } \\
\text { behaviors is a must for } \\
\text { environmentally responsible } \\
\text { consumers }\end{array}$ \\
\hline
\end{tabular}




\section{Consumers' Environmental Responsibility}

Consumers' environmental responsibility

refers to consumption activities that benefit, or result in less damage to the environment than substitutable activities (Ebreo, Hershey and Vining, 1999; Pieters, 1991).

Crosby, Gill, and Taylor (1981) defined environmental concern tentatively as a strong positive attitude toward preserving the environment. Later, they defined environmental concern as a general or global attitude with indirect effects on behaviors through behavioral intentions (Gill, Crosby, and Taylor, 1986), based on the work of Van Liere and Dunlap (1981). Zimmer, Stafford and Stafford (1994) supported this definition describing environmental concern as "a general concept that can refer to feelings about many different green issues."

Consumer Environmental Responsibility is formally defined as "a state in which a person expresses an intention to take action directed toward remediation of environmental problems, acting not as an individual consumer with his/her own economic interests, but through a citizen consumer concept of societal-environmental wellbeing. Further, this action will be characterized by awareness of environmental problems, knowledge of remedial alternatives best suited for alleviation of the problem, skill in pursuing his or her own chosen action, and possession of a genuine desire to act after having weighed his/her own locus of control and determining that these actions can be meaningful in alleviation of the problem" (Stone et al., 1995, p. 601).

\section{RESULT AND DISCUSSION}

After conducting a comprehensive and systematic review of literature, a total of six constructs have been confirmed. The following table (Table 1) summarizes the major constructs for assessing consumers' environmental responsibility followed by the detailed discussion and argument supported by corresponding literature.

\section{Knowledge and Awareness}

Environmentally responsible consumers must have knowledge and awareness of the environment (Stone et al., 1995; Maloney and Ward, 1973). Level of awareness may not always reflect the amount of information exposed to the individuals. For instance, Arcury (1990) mentions that Americans have been exposed to a plethora of environmental information for years, yet researchers have very little information about how much the public actually knows about the environment. Using a meta-analysis of 128 environmental studies, Hines, Hungerford and Tomera (1986) identified knowledge to be a must among some other variables that are reportedly associated with environmentally responsible behavior.

Hines et al. (1986) further propose an environmental behavior model in which the intention to take action is determined to be a combination of other factors including cognitive knowledge, cognitive skills, and personality variables. Cognitive knowledge, in this model, relates to an individual's awareness of existing environmental problems. Therefore, it can be hypothesized that consumers' level of knowledge and awareness of environmental issues have impact on their degree of responsibility in consumption behavior.

\section{Attitude}

A number of authors argued that attitude to be one of the elements that must be present in individuals who put on view of environmental responsibility (Dunlap and Van Liere, 1978; Kinnear, Taylorand Ahmed, 1974; Maloney and Ward, 1973; Thompson andGasteigner, 1985).

A new environmental paradigm consisting of an attitude and certain behaviors that would be engaged in by the environmentally concerned individual is necessary (Dunlap and Van Liere, 1978). These authors recognized that ecological problems stemmed in large part from more traditional attitudes and beliefs common in society. They further recommended that man should live in harmony with nature and limits should be imposed on economic growth.

Kinnear et al. (1974) posited that ecological concern was similar in context to environmental responsibility and is composed of 
Table 2: Measurement Items for Consumers' Environmental Responsibility

\begin{tabular}{|c|c|c|}
\hline Constructs & Measurement items & Source \& Justification \\
\hline $\begin{array}{l}\text { Knowledge } \\
\text { \& } \\
\text { awareness }\end{array}$ & $\begin{array}{l}\text { 1.The amount of energy I use does not } \\
\text { affect the environment to any significant degree. } \\
2 \text { The country needs more restrictions on residential } \\
\text { development (construction of a new mall on } \\
\text { farmland, new subdivisions, etc.). } \\
3 . \text { If I were a hunter or fisherman, I would kill or } \\
\text { catch more if there were no limits. } \\
4 . I \text { know very well what the term } \\
\text { 'global warming' means. } \\
5.1 \text { know very well what the term } \\
\text { 'organic product' means. } \\
6.1 \text { know very well what the term } \\
\text { 'climate change' means. } \\
7 . I \text { know very well what the term } \\
\text { 'greenhouse gas' means. }\end{array}$ & $\begin{array}{l}\text { Three (items } 1-3 \text { ) out of four } \\
\text { items in measuring awareness } \\
\text { dimension of environmentally } \\
\text { responsible consumers } \\
\text { (Stone et al., 1995), has been } \\
\text { selected. For examining the } \\
\text { knowledge dimension four } \\
\text { items (items 4-7) are proposed } \\
\text { to explore. The rationale for } \\
\text { proposing these items is that } \\
\text { they are extensively referred to } \\
\text { most studies on today's } \\
\text { environmental and } \\
\text { ecological issues. }\end{array}$ \\
\hline Attitude & $\begin{array}{l}\text { 1. There is nothing the average citizen can do } \\
\text { to help stop environmental pollution. * } \\
\text { 2. My involvement in environmental activities } \\
\text { today will help save the environment } \\
\text { for future generations. } \\
\text { 3. I would not car pool unless I was } \\
\text { forced to. It is too inconvenient. * } \\
\text { 4. It is essential to promote green } \\
\text { living in my country. } \\
\text { 5. Environmental protection works are simply } \\
\text { a waste of money and resources. * } \\
6 . \text { I strongly support that more environmental } \\
\text { protection works are needed in my country. } \\
7 \text {. Environmental protection issues are } \\
\text { none of my business. * } \\
8 . \text { I think environmental protection } \\
\text { is meaningless. * } \\
\text { 9. It is unwise for my country to spend a } \\
\text { vast of money on promoting } \\
\text { environmental protection. * } \\
\text { 10. It is very important to raise environmental } \\
\text { concern among the citizens. }\end{array}$ & $\begin{array}{l}\text { A total of ten items are proposed } \\
\text { to be used in examining } \\
\text { consumers' attitudes toward } \\
\text { environmental issues. } \\
\text { Items } 1-3 \text { are taken from } \\
\text { ECOSCALE (Stone et al., 1995) } \\
\text { and items } 4-10 \text { were used by } \\
\text { Lee (2011) in measuring } \\
\text { the same issue. }\end{array}$ \\
\hline $\begin{array}{l}\text { Green } \\
\text { consumer } \\
\text { value }\end{array}$ & $\begin{array}{l}\text { 1. It is important to me that the products I use do } \\
\text { not harm the environment. } \\
\text { 2. I consider the potential environmental impact } \\
\text { of my actions when making many of my decisions. } \\
\text { 3. My purchase habits are affected by my concern } \\
\text { for our environment. } \\
\text { 4. I am concerned about wasting the resources } \\
\text { of our planet. } \\
5 . \text { I would describe myself as }\end{array}$ & $\begin{array}{l}\text { This 6-item scale is adapted from } \\
\text { Bearden et al. (2010, pp. } 172- \\
\text { 173) where the original scale } \\
\text { was referred to Haws, } \\
\text { Winterich, and Naylor (2010) } \\
\text { who titled the scale as 'GREEN } \\
\text { scale'. One of the reasons for } \\
\text { using this scale is because it } \\
\text { has a high level of reported }\end{array}$ \\
\hline
\end{tabular}


Table. 2 Continues.

\begin{tabular}{|c|c|c|}
\hline & $\begin{array}{l}\text { environmentally responsible. } \\
6 . \text { I am willing to be inconvenienced in order } \\
\text { to take actions that are more environmentally friendly. }\end{array}$ & $\begin{array}{l}\text { internal consistency with alpha } \\
\text { value of over } .85 \text {. }\end{array}$ \\
\hline $\begin{array}{l}\text { Emotional } \\
\text { affinity } \\
\text { toward } \\
\text { nature }\end{array}$ & $\begin{array}{l}\text { 1 When I spend time in nature I feel free and easy. } \\
\text { 2. When surrounded by nature I get calmer } \\
\text { and I feel at home. } \\
\text { 3. I feel relaxed and have a pleasant feeling } \\
\text { of intimacy when spending time in nature. } \\
\text { 4. Whenever I spend time in nature I do not } \\
\text { experience a close connection to it } \\
\text { 5. Sometimes when I feel unhappy } \\
\text { I find solace in nature. }\end{array}$ & $\begin{array}{l}\text { The scale (items } 1-5) \text { has been } \\
\text { taken from Müller, Kals, and } \\
\text { Pansa (2009) which was } \\
\text { originally used by Kals, } \\
\text { Schumacher, and Montada } \\
\text { (1999) } \\
\text { with satisfying results } \\
\text { concerning reliability } \\
\text { (alpha= .86). }\end{array}$ \\
\hline $\begin{array}{l}\text { Willingness } \\
\text { to act }\end{array}$ & $\begin{array}{l}\text { 1. I want to be a member of an environmental group. } \\
\text { 2. I will provide financial support to clean up } \\
\text { the environment. } \\
\text { 3. I want to attend a rally or a demonstration on } \\
\text { an environmental issue. } \\
\text { 4. I will keep my garbage in separate piles of glass, } \\
\text { plastic, paper, newspapers, and metal for recycling } \\
\text { when they are available. } \\
\text { 5. I'd be willing to ride a bicycle or use public } \\
\text { transportation to go to work/school to reduce } \\
\text { air pollution. } \\
6 \text {. I would be willing to donate a day's worth of pay } \\
\text { to a foundation to help them improve the } \\
\text { environment. } \\
\text { 7. I strive to learn as much as possible about } \\
\text { environmental issues. } \\
\text { 8. I would pay extra on my electricity bill } \\
\text { each month to ensure that all of the electricity } \\
\text { I use comes from 'green' sources }\end{array}$ & $\begin{array}{l}\text { Items } 1-4 \text { were used by Ramly } \\
\text { et al. (2012) with a Cronbach's } \\
\text { alpha of } 0.90 \text { and items } \\
5-8 \text { were used by Tuna and } \\
\text { Özkoçak (2012) where } \\
\text { Cronbach's alpha value } \\
\text { was } 0.85 .\end{array}$ \\
\hline $\begin{array}{l}\text { Environment } \\
\text { related } \\
\text { past } \\
\text { behavior }\end{array}$ & $\begin{array}{l}\text { 1.I have switched products for ecological reasons. } \\
\text { 2.I have convinced members of my family or friends } \\
\text { not to buy some products that are harmful to the } \\
\text { environment. } \\
\text { 3. I have tried very hard to reduce the amount of } \\
\text { electricity I use. } \\
\text { 4. I have purchased a household appliance } \\
\text { because it used less electricity than other brands. } \\
\text { 5. I have replaced light bulbs in my home with } \\
\text { those of smaller wattage so that I will conserve } \\
\text { on the electricity I use } \\
6 . \text { I have purchased light bulbs that were } \\
\text { more expensive but saved energy. }\end{array}$ & $\begin{array}{l}\text { These six items reflecting } \\
\text { consumers' past behavior } \\
\text { regarding environmental issues } \\
\text { have been taken from ECCB } \\
\text { (ecologically conscious } \\
\text { consumer } \\
\text { behavior) scales used by } \\
\text { Roberts (1996a) and Straughan } \\
\text { and Roberts (1999). }\end{array}$ \\
\hline $\begin{array}{l}\text { Environ- } \\
\text { mentally } \\
\text { responsible } \\
\text { consumer } \\
\text { (behavior) }\end{array}$ & $\begin{array}{l}\text { 1.I normally make a conscious effort to limit my } \\
\text { use of products that are made of or use } \\
\text { scarce resources. } \\
\text { 2. I always try to use electric appliances } \\
\text { (e.g., dishwasher, washer, and dryer) before }\end{array}$ & $\begin{array}{l}\text { The original ECCB } \\
\text { (environmentally conscious } \\
\text { consumer behavior) scale } \\
\text { consists of } 30 \text { items used by } \\
\text { Roberts (1996a) and }\end{array}$ \\
\hline
\end{tabular}


Table. 2 Continues..

\begin{tabular}{|c|c|}
\hline $\begin{array}{l}\text { 10 P.M. and after } 10 \text { P.M. } \\
\text { 3. When there is a choice, I always choose the } \\
\text { product that contributes to the least amount of } \\
\text { pollution. } \\
\text { 4. If I understand the potential damage to the } \\
\text { environment that some products can cause, } \\
\text { I do not purchase these products. } \\
\text { 5. I use a recycling center or in some way } \\
\text { recycle some of my household trash. } \\
\text { 6. I make every effort to buy paper products } \\
\text { made from recycled paper. } \\
\text { 7. I use a low-phosphate detergent } \\
\text { (or soap) for my laundry. } \\
\text { 8. I do not buy products in aerosol containers. } \\
\text { 9. Whenever possible, I buy products } \\
\text { packaged in reusable containers. } \\
\text { 10. I will not buy a product if the company } \\
\text { that sells it is ecologically irresponsible. } \\
\text { 11. I buy toilet paper made from recycled paper. } \\
\text { 12. I try only to buy products that can be recycled. } \\
\text { 13. I do not buy household products that } \\
\text { harm the environment. } \\
\text { 14. To save energy, I drive my car as little } \\
\text { as possible. } \\
\text { 15. I try to buy energy efficient household } \\
\text { appliances. } \\
\text { 16. I usually purchase the lowest priced } \\
\text { product, regardless of its impact on society. * } \\
\text { 17. I use my own bag when shopping. } \\
\text { 18. I refuse plastic bags when shopping. } \\
\text { 19. I consume foods that are produced } \\
\text { using organic farming methods. } \\
\text { only if needed to submit for official purpose. } \\
\text { 21. I take printed copy any transaction at } \\
\text { ATM one side of the paper. * }\end{array}$ & $\begin{array}{l}\text { Straughan and Roberts (1999). } \\
\text { A total of } 16 \text { items that are } \\
\text { considered to reflect much } \\
\text { "concrete" forms of } \\
\text { environmentally } \\
\text { responsible behavior from the } \\
\text { original ECCB scale are used } \\
\text { for this study with acceptable } \\
\text { coefficient Alpha value. } \\
\text { Items } 17 \text { \& } 18 \text { are used } \\
\text { from the study of Gadenne } \\
\text { ( } 2011 \text { ). Items } 19-22 \text { have } \\
\text { been proposed by } \\
\text { the authors. }\end{array}$ \\
\hline
\end{tabular}

${ }^{\star}$ Reversed scaled items.

two dimensions: (a) an attitude that must express concern for the environment, and (b) a purchasing behavior that must be consistent with maintenance of the environment. They further indicate that the level of ecological concern is a function of both attitudes and behavior. Here attitude refers to attitude towards environmental protection and accordingly the assumption is that consumers who have positive attitude towards environmental protection show more responsibility in their consumption behavior.

\section{Green Consumer Value}

Green consumers are defined as those who have a tendency to consider the environmental impact of their purchase and consumption 
behaviors. As such, consumers with stronger GREEN values (Haws, Winterich and Naylor 2010) will tend to make decisions consistent with environmentally sustainable consumption.

\section{Emotional Affinity toward Nature}

Some researchers have begun to explore the individual's affective influences on environmental concern and behavior (Stern, 2000) that incorporates emotional affinity toward nature (Kals, Schumacher and Montada, 1999; Müller, Kals and Pansa, 2009). The authors refer Emotional Affinity toward Nature (EAN) as the extent to which a person has an emotional connection to his or her natural environment. The studies confirmed that EAN explains individual's commitment to environment to a considerable extent.

\section{Willingness to Act}

Environmentally responsible consumers are said to be willing to act for environmental betterment. One measure of the individual's probable future actions is 'verbal commitment' (Maloney and Ward, 1973). A desire to act is further claimed to be closely associated with personality factors such as the individual's locus of control, his or her attitude, and exhibited personal responsibility (Hines et al., 1986).

Berkowitz and Daniels (1964) found that individuals who scored high in social responsibility were more active in church and community affairs and were more willing to contribute their time, money, and energy to these types of activities. This is similar to having a willingness to act. Therefore, it is assumed that consumers' willingness to act and their environmental responsibility towards consumption behavior are positively correlated.

\section{Action Taken/Environment Related Past Behavior}

In addition to having attitude and knowledge, the engagement in certain behaviors is a must for environmentally responsible consumers (Bennet, 1974; Dunlap and Van Liere, 1978). Maloney and Ward (1973) argued that both attitude and knowledge determine the environmentally relevant behaviors that encompass actions that individuals presently pursuing or would be willing to pursue. Hines et al. (1986) emphasized the necessity of 'actual commitment' as a measure of an individual's present behavior. Apparently consumers' environmental responsibility is said to be reflected in their environment related past behavior.

\section{Consumer Demography}

Several studies in the past have attempted to investigate and found that some demographic variables of consumers correlate with environmentally conscious consumption behavior. A review of these studies and their findings in accordance to the select demographic variables are outlined in the following section. This summary is mainly referred to the work of Straughan and Roberts (1999).

\section{Age}

Age has been explored by a number of early studies of ecology and green marketing (e.g. Roberts, 1995; 1996b; Roberts and Bacon, 1997; Roper, 1990; 1992; Samdahl and Robertson, 1989; Van Liere and Dunlap, 1981; Zimmer et al., 1994). One general consensus regarding age is that the younger people are likely to be more sensitive to ecological issues. The most common argument for this general consensus is that the people, who grew up in the time of growing concern of environmental issues at some level, are more likely to be sensitive to these issues (Straughan and Roberts, 1999). Ironically, this trend has been found to be reversed in several studies over the last two decades (D'Souza et al., 2007; Jain and Kaur, 2006; Roberts, 1996a, 1996b; Samdahl and Robertson, 1989).

In fact, like other demographic variables, the findings of the relationship with age and green consumer behavior are not identical. Some studies explored that the relationship between age and green behavior is non-significant (e.g. Roper, 1990; 1992) whereas others revealed the relationship to be significant and negatively correlated (e.g. Van Liere and Dunlap, 1981; Zimmer et al., 1994). Yet some studies found the relationship to be significant, but positively correlated (e.g. Roberts, 1996a; Samdahl and Robertson, 1989).

\section{Sex}

As is the case of age, the studies on the impact of gender on green behavior have not come to be conclusive yet. Straughan and Roberts (1999) 


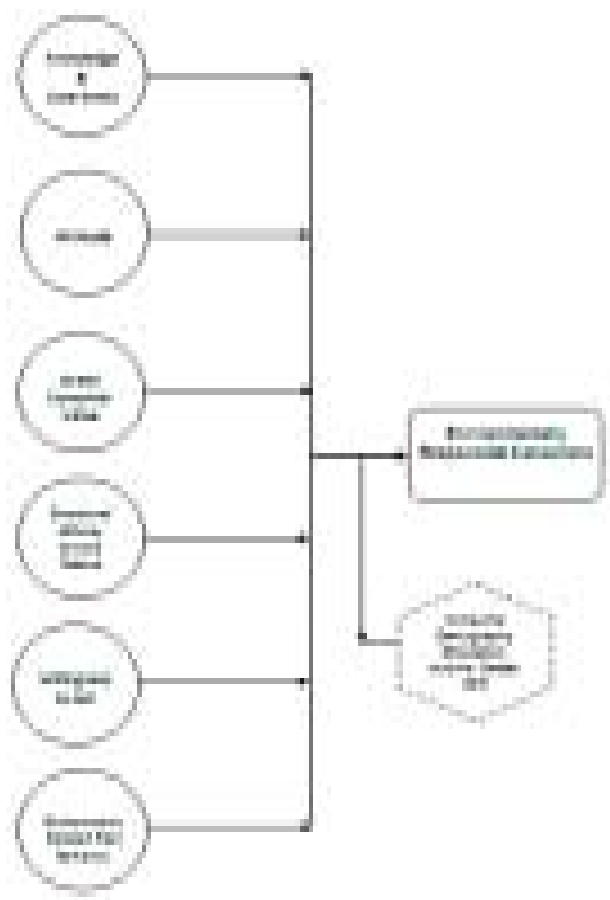

Fig. 1: Conceptual Model for Environmentally Responsible Consumers

argue that women are more likely than men to hold attitudes consistent with the green movement due to the development of unique sex roles, skills, and attitudes. Eagly (1987) justifies this inclination of women as their careful consideration of the impact of their actions on others which result from social development and sex role differences. Arcury (1990) suggested that an individual's gender may be a factor in the amount of environmental knowledge he or she possesses as well as the amount of concern the individual displays for the environment.

\section{Income}

Environmental sensitivity is generally believed to be positively related to income (Straughan and Roberts, 1999). The authors argue that generally people with higher income can afford the green products which are usually higher in price than the price of conventional products. Income has been considered as one of the predictors of ecologically conscious behavior in several early studies (e.g. Newell and Green, 1997; Roberts, 1995; 1996b; Roberts and Bacon, 1997; Roper, 1990; 1992; Samdahl and Robertson, 1989; Van Liere and Dunlap, 1981; Zimmer et al., 1994). However, few studies found the negative relationship between income and environmental concern (e.g. Roberts, 1996a; Samdahl and Robertson, 1989).

\section{Education}

Level of education is considered to be linked to environmental attitude and behavior (e.g. Newell and Green, 1997; Roberts, 1995; 1996b; Roberts and Bacon, 1997; Roper, 1990; 1992; Samdahl and Robertson, 1989; Schwartz and Miller, 1991; Zimmer et al., 1994). Most of the studies agreed that education is expected to be positively correlated with environmental concerns and behavior (Straughan and Roberts, 1999). While most of the studies come up with positive correlation between education and environmental issues, Samdahl and Robertson (1989) found the opposite, that education was negatively correlated with environmental attitudes.

\section{Proposed Conceptual Model for Environmentally Responsible Consumers}

The following figure (Figure1) displays the proposed conceptual framework representing the possible constructs for measuring consumers' environmental responsibility. In addition to the selected six constructs, selected consumer demographics are proposed to be incorporated in the model to investigate any mediating or moderating impact on consumers' environmental responsibility.

\section{Items for Measuring the Constructs}

A comprehensive literature review has been conducted for compiling a reliable set of scale items for measuring the constructs and testing the proposed model. The following table summarizes the scale items with their corresponding constructs and references.

\section{ACKNOWLEDGMENTS}

This study was conducted with the funding support from HiCOE project at Institute for Environment and Development (LESTARI), UKM (XX-05-2012). The authors would like to thank the funding body for supporting the study. The authors also would like to thank the research scholars for their research works that have been used in this study as the sources of data. 


\section{REFERENCES}

1. Arcury T. A. Environmental attitudes and environmental knowledge, Human Organization, 49, 300-304 (1990).

2. Bearden W. O., Netemeyer R. G. and Haws K. L. Handbook of Marketing Scales: MultiItem Measures for Marketing and Consumer Behavior Research. $3^{\text {rd }}$ Edition. SAGE Publications, 168-171 (2011).

3. Bennet D. B. Evaluating environmental education programs. In J. A. Swain \& W. B. Stapp (Eds.), Environmental Education ( 113-164). New York: John Wiley \& Sons, Inc. (1974).

4. Berkowitz L., and Daniels L. R. Affecting the salience of the social responsibility norms. Journal of Abnormal and Social Psychology, 68: 275-281. (1964).

5. Crosby L. A., Gill J. D. and Taylor J. R., Consumer/voter behavior in the passage of the Michigan Container Law, Journal of Marketing, 45, 19-32 (Spring 1981).

6. D'Souza C., Taghian M., Lamb P. and Peretiatkos R. Green decisions: demographics and consumer understanding of environmental labels, International Journal of Consumer Studies: 31(4), 371 (2007).

7. Dunlap R. E. and Van Liere K. D. The new environmental paradigm, Journal of Environmental Education, 9, 10-19 (1978).

8. Eagly A.H., Sex differences in social behavior: a social-role interpretation, Lawrence Erlbaum Associates, Hillsdale, NJ. (1987).

9. Ebreo A., Hershey J. and Vining J. Reducing solid waste: linking recycling to environmentally responsible consumerism, Environment and Behaviour, 31: 107-134 (1999).

10. Gadenne D., Sharma B., Kerr D. and Smith T. The influence of consumers' environmental beliefs and attitudes on energy saving behaviours, Energy Policy, 39: 7684-7694 (2011).

11. Gill J. D., Crosby L. A. and Taylor J. R., Ecological concern, attitudes, and social norms in voting behavior, Public Opinion Quarterly, 50: 537-554 (1986).
12. Grunert S. C., What's green about green consumers besides their environmental concern? 22nd Annual Conference of the European Marketing Academy, 2: (1993).

13. Haron S. A., Paim L. and Yahaya N. Towards sustainable consumption: an examination of environmental knowledge among Malaysians, International Journal of Consumer Studies, 29(5), 426-436 (2005).

14. Hart C., Doing a literature review: Releasing the social science research imagination, Sage (1998).

15. Haws K. L., Karen P. W. and Rebecca W. N., Seeing the world through green-tinted glasses: motivated reasoning and consumer response to environmentally friendly products, Working Paper, Texas A\&M University, College Station, TX77843 (2010).

16. Hines J. M., Hungerford H. R. and Tomera A. N., Analysis of research on responsible environmental behavior: a meta-analysis, Journal of Environmental Education, 18: 1-8 (1986).

17. Jain S. and Kaur G. Role of sociodemographics in segmenting and profiling green consumers: an exploratory study of consumers in India, Journal of International Consumer Marketing, 18(3), 107-117 (2006).

18. Kals E., Schumacher D. and Montada L. Emotional affinity toward nature as a motivational basis to protect nature, Environment and Behavior, 31: 178-202 (1999).

19. Kinnear T. C., James C. T. and Sahrudin A. A., Ecologically concerned consumers: who are they? Journal of Marketing, 38 (April), 20-24 (1974).

20. Lee $\mathrm{K}$. The role of media exposure, social exposure and biospheric value orientation in the environmental attitude-intentionbehavior model in adolescents, Journal of Environmental Psychology, 31: 301-308 (2011).

21. Magrabi F.M., Chung Y.S., Cha S.S. and Yang S., The Economics of Household Consumption. Praeger, New York (1991).

22. Maloney M. P. and Ward M. P., Ecology: Let's bear it from the people. American 
Psychologist, 28: 583-586 (1973).

23. Miran B., Günden C. and Sahin A., Awareness to environmental pollution, presented at Southern Agricultural Economics Association Annual Meeting, Dallas (2008).

24. Müller M.M., Kals E. and Pansa R., Adolescents' emotional affinity toward nature: a cross-societal study, The Journal of Developmental Processes, 4(1): 59-69 (2009).

25. Newell S.J. and Green C.L., Racial differences in consumer environmental concern, The Journal of Consumer Affairs, 31(1): 53-69 (1997),

26. Pieters R.G.M., Changing garbage disposal patterns of consumers: motivations, ability and performance, Journal of Public Policy and Marketing, 10: 59-77 (1991).

27. Ramly Z., Hashim N.H., Yahya W.K. and Mohammad S.A., Environmentally conscious behavior among malaysian consumers: an empirical analysis, JurnalPengurusan, 35: 111-121 (2012).

28. Randolph J.J., A Guide to Writing the Dissertation Literature Review.Practical Assessment, Research \& Evaluation, 14: 2 (2009).

29. Roberts J.A., Profiling levels of socially responsible consumer behavior: a cluster analytic approach and its implications for marketing, Journal of Marketing Theory and Practice, Fall, 97-117 (1995).

30. Roberts J. A., Green consumers in the 1990s: profile and implications for advertising, Journal of Business Research, (3): 217231 (1996a).

31. Roberts J. A., Will the real socially responsible consumer please step forward? Business Horizons, 33, 79-83 (1996b).

32. Roberts J.A. and Bacon D.R., Exploring the subtle relationships between environmental concern and ecologically conscious consumer behavior, Journal of Business Research, 40(1): 79-89 (1997).

33. Roper Organization, The Environment: Public Attitudes and Individual Behavior, Commissioned by S.C. Johnson and Son, Inc. (1990).
34. Roper Organization, Environmental Behavior, North America: Canada, Mexico, United States, Commissioned by S.C. Johnson and Son, Inc. (1992).

35. Samdahl D.M. and Robertson R., Social determinants of environmental concern: specification and test of the model, Environment and Behavior, 21(1), 57-81 (1989).

36. Stern P.C., Toward a coherent theory of environmentally significant behavior, Journal of Social Issues, 56( 3), 407-424 (2000).

37. Straughan R.D. and Roberts J.A., Environmental segmentation alternatives: a look at green consumer behavior in the new millennium, Journal of Consumer Marketing, 16(6), 558-575 (1999).

38. Schwartz J. and Miller T., The earth's best friends, American Demographics, 13 (February), 26-35 (1991).

39. Stone G., James H. B., and Cameron M., ECOSCALE: a scale for the measurement of environmentally responsible consumers, Psychology \& Marketing, 12: 595-612 (1995).

40. Thompson J. C, Jr. and Gasteigner E. L., Environmental attitude survey of university students: 1971-1981, Journal of Environmental Education, 17: 13-22 (1985).

41. Trott M., Sustainable Consumption: Issues and Challenges. Indeco Strategic Consulting, Toronto, Canada (1997).

42. Tuna Y. and Özkoçak L., The first step to communication with environmentally responsible consumer: measuring environmental consciousness of Turkish consumers, Online Journal of Communication and Media Technologies, 2(3): (2012).

43. Van L. K. and Dunlap R., The social bases of environmental concern: a review of hypotheses, explanations, and empirical evidence, Public Opinion Quarterly, 44(2): 181-97 (1981).

44. Zimmer M.R., Stafford T.F. and Stafford M.R., Green issues: dimensions of environmental concern, Journal of Business Research, 30(1): 63-74 (1994). 